\title{
Children's Language Acquisition with Islamic Animated Video Media "Nussa" on Two-Year-Old Kid (Qualitative Study on Nareshwara)
}

\author{
Meilan Arsanti ${ }^{1}$, Aris Destria ${ }^{2}$ \\ Sultan Agung Islamic University ${ }^{1}$, SMA N 5 in Tegal City ${ }^{2}$ \\ \{meilanarsanti@unissula.ac.id ${ }^{1}$, destriaris2@gmail.com²
}

\begin{abstract}
Golden age is the age of the child at the beginning of his life starting from the age of $0-5$ years. At this time the child is in their best development for his physical and brain. At this age the child begins to know the mother language especially to learn speaking. Because the process of obtaining each child's language is different, researchers focused the acquisition of the child's language in a two-year-old named Nareshwara Digdya Ganapatih. In this study, researchers used islamic animated media titled "Nussa" to provide stimulus for the acquisition of Nareshwara language, especially vocabulary related to Islam. This research was conducted to describe the acquisition of children's language especially vocabulary related to Islam obtained by Nareshwara after watching the animated video of Islami "Nussa". Research is done by qualitative methods with a descriptive approach. Researchers use data collection techniques with simak (paying attention), cakap (interview) and record techniques. From the results of the study it is known that Nareshwara obtained 9 vocabulary including 1) Allahu Akbar, 2) adhan, 3) salat, 4) wudoo' , 5) pray, 6) asalamualaikum, 7) bismillahirrohmanirrahim, 8) alhamdulillah, 9) masya Allah, and 10) aamiin. The words have not been pronounced perfectly because only the latest syllable can only be spoken in words that exceed two syllables. Thus, it can be concluded that the acquisition of children's language, especially vocabulary related to Islam can be helped by the media of islamic animated video "Nussa". This can be recommended to parents who want to improve their child's language.
\end{abstract}

Keywords : child language acquisition, animated video of Islamic Nussa, twoyear-old kid, golden age

\section{Introduction}

Golden age is the age of the child at the beginning of his life starting from the age of $0-5$ years. At this time the child is in their best development for his physical and brain. At this age the child begins to know mother language especially to learn speaking. Children's speaking skills should be taught as early as possible according to their level of development and age. As parents, it is supposed not be too late to teach the child talking because it will affect other skills.' 
'It is quoted from The Asianparent Indonesia page that the baby's speech ability is starting to appear depending on the surrounding environment. Firstly, the vocal sounds that the baby will create at the age of 2-3 months. The baby begins to use his tongue, lips, palate, and teeth to make certain sounds. Babies will also start babbling at the age of 4 months before finally being turned into a real word. Next, the baby will start imitating the words he hears from the surrounding environment. When the baby starts to turn 18 months old to 2 years old, he will start saying 2 to 4 words. Over time the baby is able to improve his vocabulary to describe what he sees, hears, tastes, thinks, and what he wants. The number of children's vocabulary depends on their language acquisition. This is because each child has different language development and acquisition [9].

Language acquisition or language acquisition is a process that takes place in a child's brain when he or she acquires his first language or his mother tongue. Language acquisition is usually distinguished from language learning. Language learning relates to the processes that occur when a child learns a second language, after he or she has obtained his first language. Thus, language acquisition is related to the first language, while language learning is related to the second language [5]. The acquisition of the child's language does not actually begin at the time of the child's birth, but is begun while still in the womb. Many studies have revealed that fetuses in the womb that are accustomed to communicating can make children born intelligent. Language acquisition in children has a profound effect on cognitive development. According to language ability is one indicator of a child's cognitive development [3]

Based on this, golden age is an important time for the child's life, so that parents should optimize the growth of their children. Providing stimulus and response during this golden age is very important in training the development of children's language. There are many methods that parents can do to stimulate their child's language development. Especially in today's modern age and with the sophistication of technology a lot of information that can be utilized by parents in terms of growing up including about the acquisition of children's language. Nowadays it is no longer a rare sight where parents give their child the opportunity to watch or listen to videos through a YouTube channel. The sophistication of technology and ease of access make parents from children to even babies unable to be separated from videos on YouTube including Nareshwara. Nareshwara is the first child of the researchers themselves who is now 2 years old. Nareshwara has been introduced to Youtube videos since the age of 12 months. One of nareshwara's most watched videos is Nussa's. The video is very interesting and suitable for his age.

It is quoted from Wikipedia Indionesia that Nussa is an Indonesian animated series produced by animation studio The Little Giantz and 4Stripe Productions. The animation has been on video sharing service YouTube since November 2018. This animation has been aired through two free television channels /FTA Indonesia NET during Ramadan 1440 H/2019 M, Indosiar since October 2019, and Malaysian pay channel Astro Ceria in the same year [1]. Many islamic values are taught through the story on Nussa's video. In addition to the story of Islamic values is also seen in the language used such as greetings, tahmid readings, verse excerpts of the Qur'an and hadith, prayer readings, and others. This can of course be utilized for the development of the language of children who are learning to speak. In addition, islamic values in the video can also be used to dedid religious characters in children.

In this study, researchers used an Islamic animated medium titled "Nussa" to provide stimulus to the acquisition of Nareshwara language, especially vocabulary related to Islam. Woozley states that language learning is a process of habit formation resulting from input and positive reinforcement habits from the right as well as negative reinforcement of mistakes [1] A child is a blank canvas in learning language as a set of habits through imitation. Mistakes 
are seen as an unwanted distraction from existing habits in childfirst language. Based on the theory, it is very appropriate if the child is given a positive stimulus in order to become a good habit to form his character in the future. This is because the child is like a blank canvas that must be filled with habits through imitations of the parents and their surroundings. Due to the process of obtaining each child's language is different, researchers focused the acquisition of the child's language in a two-year-old named Nareshwara Digdya Ganapatih. This research was conducted to describe the acquisition of children's language especially vocabulary related to Islam obtained by Nareshwara after watching the animated video of Islami "Nussa".

\section{Research Methods}

This research was conducted by qualitative method with a descriptive approach. Qalitative research is a research that intends to understand phenomena about what the subjects research experience such as behavior, perception, motivation, action, etc. holistically, and by a way of description in the form of words and language, in a special context that is natural and by utilizing various natural methods [6]. Descriptive is a method that serves to describe or provide an overview of the objects studied through the data or samples that have been collected as they actually are, without performing analysis and making general conclusions [8].

In this study, a descriptive approach was used to describe the research data that nareshwara obtained after watching Nussa's video. The vocabulary in question is a vocabulary related to Islam. Due to the qualitative methods used in this study, then the researchers themselves became instruments of research. In qualitative research the instrument is the researcher himself so that in order to become an instrument then the researcher must have a wide supply of theories and insights, so that it is able to ask, analyze, photograph, and construct the objects studied to become clearer and meaningful [8]. Researchers used data collection techniques with simak (paying attention), cakap (interview) techniques, and also recorded to document every word Nareshwara spoke after watching Nussa's video. Once the data is collected the data is analyzed by triangulating the data.

The study was conducted for approximately 6 months from Nareshwara aged 18 months to 24 months. Nareshwara as a research subject almost watches Nussa videos everyday from morning to night according to her wishes accompanied by her parents. Nussa's video was downloaded from the Youtube page and then aired on television in her room. This is done to reduce radiation if watching from the gadget although sometimes Nareshwara watches the vidoe from the gadget. Nussa's videos were watched by 15 different story series. Nareshwara watches the video as he pleases by playing, sometimes while sleeping even to sleep. Often Nareshwara watches the video while eating or drinking milk (breast milk).

\section{Research and Discussions Results}

\subsection{Research Results}

During the research process there were 15 series of Nussa animated video stories that Nareshwara watched. The title of each video series can be seen in the following table. 
Table 1. The Title Series of Nussa Animated Video

\begin{tabular}{cl}
\hline Num & \multicolumn{1}{c}{ Title } \\
\hline 1 & Fear of Sleep Alone \\
2 & Smile is Charity \\
3 & Playing Kite \\
4 & The Powerful of Basmalah \\
5 & Eat, Don't Eat Carelessly \\
6 & It's Already Azan, Don't be Noisy! \\
7 & Friday Feast Day \\
8 & Learning To Be Sincere \\
9 & Don't be Wasteful \\
10 & Who We Are \\
11 & Prayer Is Obligatory \\
12 & A Treat Competition \\
13 & Beingin Love with Vegetables \\
14 & Rarra's New Friends \\
15 & Wash your Hand \\
\hline
\end{tabular}

After watching the animated video Nussa vocabulary obtained by Nareshwara can be seen in the following table.

Table 2. Acquisition of Language and Pronunciation of Nareshwara

\begin{tabular}{lll}
\hline No & Words & Pronunciation \\
\hline 1 & Allahu Akbar & lah abang \\
2 & Adzan & dan \\
3 & Salat & lat \\
4 & Wudu & udu \\
5 & Berdoa & oa \\
6 & Asalamualaikum & kum \\
7 & bismillahirrohmanirrahim & him \\
8 & Alhamdulillah & lah \\
9 & masya Allah & sa lah \\
10 & aamiin. & amin \\
\hline
\end{tabular}

\subsection{Discussion}

\subsubsection{Vocabulary Obtained by Nareshwara}

From the results of the study it is known that after watching nussa animated videos, Nareshwara obtained 9 new vocabulary related to Islam. The vocabulary includes 1) Allahu Akbar, 2) adzan, 3) prayer, 4) wudoo' , 5) pray, 6) assalamualaikum, 7) bismillahirrohmanirrahim, 8) alhamdulillah, 9) masya Allah, 10) aamiin, which can be described as follows.

\section{a) Allahu Akbar}

The word Allahu Akbar was obtained by Nareshwara after watching Nussa's animated video entitled Salat Itu Wajib. The word is then spoken in daily life especially when seeing his 
parents pray. Nareshwara often imitates when his father became an imam and uttered Allahu Akbar takbir. Nareshwara means that the word Allahu Akbar means prayer. Here's the vocabulary nareshwara pronounces.

$$
\begin{array}{ll}
\text { Mother } & \text { : "What's daddy doing, son?" } \\
\text { Nareshwara } & \text { : "Lah abang." (Allahu Akbar) } \\
\text { Mother } & \text { : "Masya Allah how smart Ayesh is." }
\end{array}
$$

\section{b) Adzan}

In the video series titled It's Already Azan, Don't Be Noisy! Nussa and Rarra were having fun playing at home and then heard the sound of adhan from the mosque. Their mother warned them not to be noisy because they were adhan. Nussa and Rarra fell silent for a moment to listen to the sound of the adhan and rushed to bath room for wudoo' and to pray. From the serial of the video Nareshwara got a new vocabulary that is the word adhan. Nareshwara does not yet understand that azan is a sign of entering prayer time, but he understands that if there is an adhan then it must be prayer. Here is the vocabulary spoken by Nareshwara while watching the TV.

$$
\begin{array}{ll}
\text { Nareshwara } & : \text { "Nda, dan Nda." } \\
\text { Mother } & : \text { "Yes son, it is the adhan of mahrib prayer. Let’s pray with Mother." }
\end{array}
$$

In addition to understanding the adhan while watching on TV, Nareshwara also understood the sound of the adhan he heard from a mosque near home.

\section{c) Prayer}

After being able to imitate takbir readings, Nareshwara also gained a new vocabulary after watching Nussa's animated video entitled Salat Itu Wajib which is the word prayer. In that series, Nussa as the main character wakes her sister named Rarra who is still asleep anyway even though she has not done the (Subuh) dawn prayers. Nussa tries to wake her sister by splashing the drinking water on Rarra's room table. Shocked there was a trickle of water on his face then Rarra woke up, but had not rushed to (Subuh) dawn prayers. Seeing that his mother came to the room and explained that prayer was mandatory even for a small child like Rarra. Eventually Rarra realized and immediately woke up to wudoo' and perform the (Subuh) dawn prayers. The word prayer is interpreted by Nareshwara as Allahu Akbar. Here's the vocabulary nareshwara pronounces.

Nareshwara : : "Nda." (whining does not want to be left by his mother prayer)

Dad : "Here with Daddy, son, mother want to sa...?" (stimulate to continue the word of prayer)

Nareshwara : "Lat."

Dad : : "Smart boy." 


\section{d) Wudoo'}

In Nussa's animated video entitled Salat Itu Wajib, Nareshwara obtained three vocabularies namely Allahu Akbar, salat, and wudoo' . He also understands that before doing prayer must wudoo' first. Here's the vocabulary nareshwara pronounces.

Mother : : "Ayesh here used to be with dad yes, mother wants to wu...?"

Nareshwara : :Du."

Mother : : "Alhamdulilah Ayesh is a great son."

\section{e) Du'a}

Nussa's next animated video adds to Nareshwara's new vocabulary titled The Powerful of Basmalah. In the video Nussa and Rarra are on a bike with their cat named Anta. Suddenly in the middle of the road Anta is seduced by the devil so he moves around at Rarra's sling. Due to the tight enough movement Nussa could not maintain balance and eventually fell. After falling they only realized that before riding the bike must pray first by saying bismillah. Here's the vocabulary nareshwara pronounces.

Mother : : Ayesh if riding a bike do not forget to du'..?"

Nareshwara : "A."

\section{f) Assalamualaikum}

All of Nussa's animated videos begin with Rarra greeting "Assalamualaikum". When nussa and Rarra enter her house also say salam. Nareshwara gets a new vocabulary assalamualaikum then spoken in daily life. Here's the vocabulary nareshwara pronounces.

Mother : : "Son, if you come in the house say salam first."

Nareshwara : : "Kum." (while knocking on the door)

In addition to being spoken at home, nareshwara also said the vocabulary at the time of entering his baby sitter's house and at the time of his parents' pick up. Here's the dialogue.

Mother : : "Budhe, Ayes go home first. Assalamualai.."

Nareshwara : : "Kum."

Nanny : : "What A Shaleh Son. Waalaikumsalam warrah matullahi wabarrokatu."

\section{g) Bismillahirrohmanirrahim}

As in Nussa's animated video The Power of Basmalah, Nareshwara also acquires a new vocabulary called bismillahirrohmanirrohim. The new vocabulary spoken by Nareshwara has not been pronounced perfectly. He can only speak 1-2 syllables so that only pronouncethe last syllable. Here is the vocabulary that Nareshwara spoke when taken for a walk in his parents' car.

Dad : : "Let's go for a walk by car, Son."

Mother : : "Do not forget to pray bimillahirrohmanirro ..." 


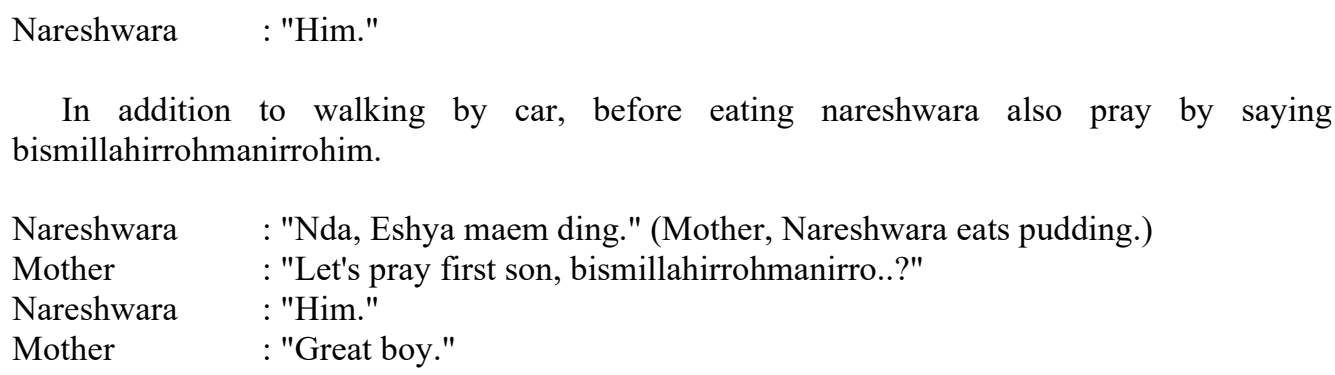

\section{8) Alhamdulillah}

In addition to the word bismillahirrohamnirrohim, the word alhamdullillah is also often spoken by Nussa and Rarra during activities in each animated video series. This word adds a new vocabulary to Nareshwara. Here's an example of Nareshwara's conversation with her parents.

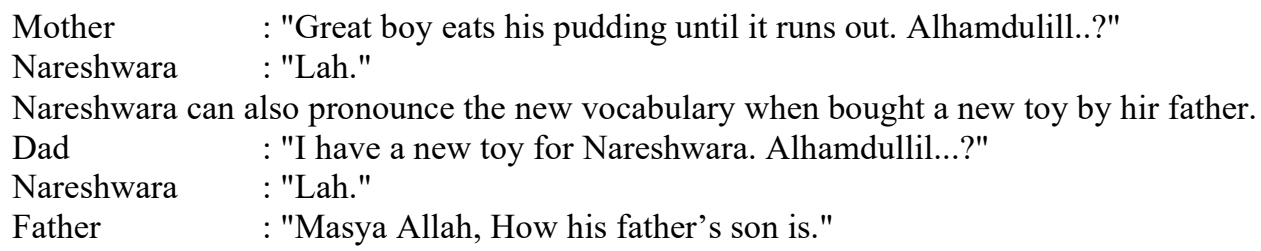

\section{9) Masya Allah}

In the series titled Playing Kite, Nussa and Rarra's mother says Masya Allahwhen she sees the weather outside were very shiny. Instead of just scrambling for gadgets, Nussa and Rarra's mother suggested playing kites in the courtyard next to their home. Then Nussa and Rarra were given a kite by their mother and they happily played kite. Nareshwara was thrilled to see the video when Nussa and Rarra's mother said Masya Allah. Nareshwara instantly mimics the vocabulary when watching the same video.

Mrs. Nussa : "Masya Allah, the weather outside is beautiful." (in video)

Nareshwara : : "Sa Lah." (chuckles)

\section{0) Aamiin}

Aamiin's vocabulary was acquired by Nareshwara after watching a video of Nussa's series titled Eat, Don't Eat Carelessly. In the video series Nussa and Rarra teach a manner to eat while singing. Before eating Nussa and Rarra read the prayer first and say aaminn at the end of the prayer. Nareshwara does not understand the word aamiin. In addition to hearing after watching the video, Nareshwara heard the word aamiin at the time his father became a Imam Sholah and read alfatihah's verse. Then his mother taught Nareshwara the reading of alfatihah even though he could only say aamiin. Here's Nareshwara's conversation.

Mother : "Let's recitate Quran, son. Read alfatihah ya, ghoiril mahdu bialaihim waladdolin." 
$\begin{array}{ll}\text { Nareshwara } & \text { : "Amiin." } \\ \text { Mother } & \text { : "Masya Allah How a sholeh my child is." }\end{array}$

When his parents were in jamaah prayer and at the end of the reading Alfatihah Nareshwara also said aamiin.

\subsubsection{Acquisition of Nareshwara Language}

Based on the results, the new 10 vocabulary study obtained by Nareshwara after watching the animated video Nussa is still pronounced imperfect. Only the last syllables can only be spoken. That's because Nareshwara is only 24 months old or 2 years old whose speech is not perfect. Nareshwara, however, is a smarter kid among friends his age who haven't even spoken one bit. Nareshwara was able to say the word father at the age of 9 months. After the age of 12 months the development of Nareshwara language developed rapidly with the development of his motoric. A child's language evolves from simple to complex in a predictable pattern in each individual. The development of the child's language is a combination of social interaction, emotional development, cognitive ability, and physical/ motor development [7].

Children's language is characterised in general by the patterns that arise to including 1) crying, 2) gurgling (groping) and squealing, 3) laughing out loud, 4) localization, 5) laughing with your mouth closed, 6) talking, 7) calling with one word (Echolalia, example: "ma-mama-ma"), 8) syllables (vocables) which means sound approaching a word but with child creation, 9) expressive chatter (sounds like real but indistinguishable conversations, 10) repeating words when persuaded, 11) binding words that can be distinguished in chat expressive, 12) holophrases or sentences with one word ("milk" can mean "i want milk" or "where is my milk?"), 13) telegraphic speech or two-word sentences ("ma juice" can mean "my mama wants juice", "my mama spills juice", or "this is mama's juice") , 14) overgenarlized speech or common words /mentions ("boots" may be the surname of a dog but children use it for the name of a neighbor's cat or other animal's name), 15) undergeneralized speech or the mention of a person's child (e.g. the name of the mother is Wati; therefore, Wati's aunt cannot be called Wati; she must be called by another name), 16) conversational turnaround, 17) creative words (words usually needed to find unlearned words or the child has no frame of reference), 18) curiosity of verbal words, and 19) curiosity of printed words. In this case the Nareshwara language corresponds to the characteristicof number 8 which is vocables [7]. Based on the category of age of acquisition of Nareshwara language at the level of word combination (18-24 months). Here are the stages of language development [2].

Tabel 3. Language Development Stages

\begin{tabular}{|c|c|c|c|}
\hline No & Level & Age & Skill \\
\hline 1. & Pre Speaking & $\begin{array}{l}\text { Newborn- } \\
10 \text { Months }\end{array}$ & $\begin{array}{l}\text { 1. Development of sound (perception and results). } \\
\text { 2. Signal development. } \\
\text { 3. Addition of sound perception; baby talk is the result } \\
\text { of crying and commotion; playing with sound } \\
\text { includes repeating talk to others starting at } 3 \text { months } \\
\text { old; between six (6) to ten (10) months can use } \\
\text { consonant and limited vocal letters. }\end{array}$ \\
\hline
\end{tabular}




\begin{tabular}{|c|c|c|c|}
\hline No & Level & Age & Skill \\
\hline 2. & $\begin{array}{l}\text { The first } \\
\text { words of } \\
\text { appearing the } \\
\text { name }\end{array}$ & $\begin{array}{c}10-13 \\
\text { Months }\end{array}$ & $\begin{array}{l}\text { 1. Understanding the single word. } \\
\text { 2. Generate a single word. } \\
\text { 3. Individual differences in the use of a single word. } \\
\text { 4. Gesture function as word. } \\
\text { 5. Attention can be directed by the name of the object } \\
\text { (see dog, Ami, dog); from } 13 \text { months of receiving } \\
\text { vocabulary from } 17 \text { to } 97 \text { words. }\end{array}$ \\
\hline 3. & $\begin{array}{c}\text { Words } \\
\text { Combination }\end{array}$ & $\begin{array}{c}18-24 \\
\text { Months }\end{array}$ & $\begin{array}{l}\text { 1. Use of a single word with complex meanings for } \\
\text { multi-word expressions. } \\
\text { Example: "milk" (meaning it can ask for milk or ask } \\
\text { for breast milk). } \\
\text { 2. Use of word combinations for sentences. } \\
\text { Example: mama cake (i.e. mama ask for cake). }\end{array}$ \\
\hline 4. & $\begin{array}{c}\text { Language } \\
\text { Grammatical }\end{array}$ & $\begin{array}{c}20- \\
30 \text { Months }\end{array}$ & $\begin{array}{l}\text { 1. Speed of obtaining morphine. } \\
\text { 2. The development of unique language at this age, } \\
\text { such as starting to use pronouns; I, us, him, you. } \\
\text { 3. Regular use of sentences in patterns and rules. }\end{array}$ \\
\hline
\end{tabular}

\section{Conclusion}

Based on the results of the study, it can be concluded that the administration of stimulus and response in the process of obtaining children's language is very important especially in the golden age. The selection of stimulus should be adjusted to the characteristics and age of development of the child. The acquisition of children's language, especially vocabulary related to Islam, can be helped by the islamic animated video media "Nussa". This is evidenced by new 10 vocabulary related to Islam obtained by Nareshwara after watching the video. The vocabulary cannot yet be pronounced perfectly by Nareshwara because he is still 24 months old or 2 years old. The development of a child's language at the age of 18-24 months is still at the stage of word combinations, namely the use of a single word with complex meanings for multi-word expressions and the use of word combinations for sentences. Thus, researchers can recommend to parents who want to improve their child's language.

\section{Daftar Pustaka}

[1] Arsanti, Meilan. Pemerolehan Bahasa pada Anak (Kajian Psikolinguistik). Jurnal PBSI Vol 2 No 1. PBSI, FKIP, Unissula. (2014)

[2] Brophy, Julia; Statham, June; Mosa Peter. Playgroup in Practice Self-Help and Public Policy. London: HMSO. (2012)

[3] Hartanto, Fitri. Et all. Pengaruh Perkembangan Bahasa Terhadap Perkembangan Kognitif Anak Usia 1-3 Tahun. Sari Pediatri, Vol. 12, No. 6, April 2011 https://saripediatri.org/index.php/sari-pediatri/article/view/476 (2016)

[4] https://id.wikipedia.org/wiki/Nussa

[5] Chaer, Abdul. Psikolinguistik Kajian Teoretik. Jakarta: Rineka Cipta. (2009)

[6] Moleong, Lexy. Metodologi Penelitian Kualitatif. Bandung: PT Remaja. Rosdakarya. (2005) 
[7] Palupi, Yulia. Perkembangan Bahasa Anak. Proseding Seminar Nasional PGSD UPY dengan Tema Strategi Mengatasi Kesulitan Belajar ketika Murid Anda seorang Disleksia

https://www.google.com/url?sa=t\&rct=j\&q=\&esrc=s\&source=web\&cd=\&cad=rja\&uac $\mathrm{t}=8 \&$ ved=2ahUKEwjOyZGbg6vrAhXSdn0KHWLwCP4QFjALegQICBAB\&url=http $\% 3 \mathrm{~A} \% 2 \mathrm{~F} \% 2 \mathrm{Frepository}$.upy.ac.id\%2F421\%2F1\%2Fartikel\%2520yulia.pdf\&usg=AOv Vaw3HO0ge-j8z1Pf0D7Bkt6jJ (2015)

[8] Sugiyono. Memahami Penelitian Kualitatif. Bandung : ALFABETA. (2012)

[9] The Asianaparent Indonesia. Mulai Usia Berapa bayi Belajar Berbicara? Begini Tahapannya dan 5 Cara Stimulusnyahttps://id.theasianparent.com/bayi-bicara 2020 (2020) 